\title{
FRA BIG BROTHER TIL TOILETKUMMER OG MEKANISKE PROTESER - OM KUNST SOM RESSOURCE FOR OVERVÅGNINGSFORSKNING ${ }^{1}$
}

Diskussioner af overvågning har længe været spærret inde i en snæver forståelse af, hvad overvågning er, og hvad den gør ved os. Det gælder både for den offentlige polemik og for den internationale overvågningsforskning. I denne situation tilbyder kunsten friske ressourcer, som kan åbne for andre og måske overraskende erkendelser og dermed medvirke til en mere nuanceret debat, der i højere grad har øje for overvågningens mange facetter og nuancer.

Overvågning trækkes ofte ind i en kunstnerisk sammenhæng. Nogle gange lånes æstetiske kendetegn, som man f.eks. ser det i kriminalfilmens brug af grynede overvågningsbilleder. I andre tilfælde udsteder engagerede kunstnere advarsler om overvågningens undertrykkende effekter, mens endnu andre ironiserer, omdefinerer og forsøger at forandre den måde, vi tænker om overvågning på.

Det er imidlertid ét enkelt værk, nemlig George Orwells roman 1984 (Orwell), som oftest trækkes frem i diskussioner af relationerne mellem overvågning og kunst. Romanens forståelse af overvågning som udgående fra en lille gruppe magthavere, der ønsker at undertrykke og kontrollere befolkningen, er blevet en del af vores fælles kognitive baggrundstæppe og har i vid udstrækning været definerende for, hvordan overvågning er blevet forstået. Dette viser sig også i akademiske sammenhænge, hvor bogen tilsyneladende har haft stor indflydelse på, hvordan f.eks. Foucaults begreb om panoptikon er blevet læst (Haggerty; Gad $\&$ Lauritsen).

Dette er bemærkelsesværdigt og samtidig problematisk. Med fremkomsten af nye overvågningsteknologier og -aktører er det blevet tydeligt, at begrebsrammer, som i større eller mindre grad har ladet sig inspirere af 1984, ikke længere slår til. Overvågning er blevet - og har måske altid været - et mangefacetteret fænomen, som ikke lader sig indfange af en enkelt model. Men selvom dette er erkendt, har det vist sig, at både 1984 og panoptikon er sejlivede begreber (Lyon). Derfor er der brug for at kigge efter alternative fortolkninger.

1 Forfatteren ønsker at takke Anders Albrechtslund, Hasan Elahi og en anonym reviewer for værdifulde kommentarer. 
I denne situation kan forskningen med fordel kigge til kunsten, hvor der findes en række interessante bestræbelser på at reformulere overvågningsbegrebet. Artiklen vil illustrere dette gennem to eksempler, som begge skaber sprækker i den orwellske overvågningsforståelse og introducerer andre interessante aspekter.

Det ene eksempel er Hasan Elahis Tracking Transience: The Big Brother Project (Elahi Tracking Transience). Dette værk lanceres ofte med den pointe, at kunstneren gennem en omfattende selv-overvågning har overtaget Big Brothers arbejde. Men netop i denne overtagelse ligger et skifte, som tydeliggør helt andre aspekter end dem, man finder i en traditionel overvågningsforståelse. Det drejer sig ikke mindst om en trivialisering af overvågningen, som sætter spørgsmålstegn ved, hvad Big Brother egentlig kan se. Samtidig kan værket læses ind i en modstandsstrategi, hvor overvågerens arbejde bliver umuliggjort.

Det andet eksempel er Stelarcs arbejde med avancerede modifikationer af og tilføjelser til kroppen (Stelarc hjemmeside). Stelarcs udgangspunkt er, at kroppen altid har været intimt forbundet til teknologi og løbende må re-designes i takt med, at kroppens omgivelser teknificeres. Stelarcs eksperimenterende attitude kan tolkes i lyset af et optimistisk syn på, hvad man kan opnå gennem tætte forbindelser mellem krop og teknologi. Men værkerne er også blevet tolket ud fra en mere frygtsom attitude, hvor denne sammenknytning giver øgede muligheder for overvågning. Dermed tematiseres en interessant ambivalens og nogle grundlæggende forhold om krop og teknologi, som overvågningsforskningen må forholde sig til.

Valget af Elahis og Stelarcs værker bunder ikke i en påstand om, at en syntese mellem disse værker vil udgøre en særlig stærk overvågningsforståelse. Tværtimod vil det være en pointe, at overvågning ikke kan defineres en gang for alle, og at der ikke kan laves én overgribende overvågningsteori. Hvad overvågning er, må afklares gennem specifikke, empiriske analyser - og til sådanne analyser tilbyder både Elahi og Stelarc interessante ressourcer.

\section{Store B og et fangsel}

Orwells fortælling om et samfund styret af Big Brother er en fremtidsvision placeret inden for fiktionens rammer. Men i dag er det svært at sige, om 1984 bedst kan betegnes som en roman eller som en af de mest indflydelsesrige sociologibøger, der nogensinde er skrevet. Orwells sammenknytning af overvågning og totalitarisme er blevet en mega-metafor, der har bevæget sig fra fiktionens verden til den politiske og offentlige debat og til forskellige universitetsinstitutter.

Inden for overvågningsforskningen ser man talrige referencer til 1984, men den helt dominerende teori har dog været Foucaults analyse af panoptikon (Foucault). ${ }^{2}$ Umiddelbart er panoptikon en simpel arkitektonisk mekanisme, som egentlig har

2 Inden for overvågningsforskningen er det panoptiske princip blevet videreudviklet i en række sammenhænge, hvilket betegnelser som "det elektroniske panoptikon" (Lyon), "superpanoptikon" (Poster) og "postpanopticisme” (Boyne) vidner om. 
generel værdi, men som oftest diskuteres i forhold til fængsler. Forstået således er der tale om, at man bygger fængslet cirkulært med et vagttårn i midten. Fra dette tårn kan man se alt, hvad der foregår i cellerne, som er placeret i periferien. Men fra cellerne kan man ikke se ind i vagttårnet. Det betyder, at der kan være en overvågende vagt til stede, men der behøver ikke at være det. Dette medfører en høj grad af effektivitet, fordi fangerne er nødt til at gå ud fra, at de faktisk bliver iagttaget og handle ud fra denne antagelse. Dermed bliver det ikke selve vagtens overvågning, men antagelsen om overvågningen, der medfører fangernes selv-disciplinering.

Foucaults analyse af panoptikon, eventuelt anvendt i samklang med begreberne om f.eks. biopolitik og governmentality, kunne utvivlsomt bidrage til en væsentlig nuancering af overvågningsbegrebet. Men inden for overvågningsforskningen har det ikke været kutyme at anvende Foucaults arbejde på denne måde. Tværtimod ser det ud til, at panoptikon i vid udstrækning er blevet læst ind i et orwellsk perspektiv (Simon). Det har medført, at panoptikon ikke fremstår som et alternativ til 1984, men derimod nærmere som en befæstning af Orwells overvågningsforståelse.

Idealtypisk kan man fremhæve følgende centrale punkter i en sådan 1984/ panoptikon-forståelse (Gad \& Lauritsen):

- Overvågning relateres til situationer med total synlighed. Big Brother ser alt, og fangen i det panoptiske fængsel har ingen steder at skjule sig.

- Overvågning udføres fra et center. Big Brother er placeret i samfundets centrum, ligesom vagttårnet er placeret i midten af det panoptiske fængsel.

- Overvågning er en næsten automatisk proces. Teknologierne er på plads, og vi får ikke viden om, hvad det kræver at udføre og vedligeholde overvågningen.

- Overvågningen er så effektiv, at modstand er håbløs. Den indsatte i det panoptiske fængsel har ikke andet valg end at adlyde, og hovedpersonen i 1984 forsøger et oprør, men besejres nemt af Big Brother.

I kølvandet på denne fortolkning følger et fokus på overvågningens effekter og en normativ attitude, hvor "overvågning”, "overvågningssamfund” og "overvågningsteknologi” med en høj grad af automatik behandles kritisk (Gad \& Lauritsen). Overvågning ses som en trussel mod individets kontrol over eget liv og i en videre forstand mod det demokratiske samfund. Logikken er, at overdreven brug af overvågningsteknologi fører til undertrykkelse, totalitarisme og tab af privacy.

I de senere år har der imidlertid inden for overvågningsforskningen spredt sig en erkendelse af, at 1984/panoptikon ikke er tilstrækkelig for en forståelse af nutidige overvågningsfænomener. F.eks. argumenterer Haggerty for, at panoptikons mure skal "rives ned" (Haggerty), ligesom Aas og kollegaer taler om "den panoptiske spændetrøje” (Aas et al). Kritikken er i vid udstrækning udsprunget af den empiriske iagttagelse, at overvågning i stigende grad gennemtrænger moderne samfund, men i forskellige iklædninger og med forskellige konsekvenser. Det er således blevet klart, at overvågning ikke kun udføres af staten, men også af mange organisationer (internettjenester, forsikringsselskaber, kommuner etc.) og af almindelige borgere, 
der filmer hinanden med kameraet i deres mobiltelefon (Koskela). Ser man nærmere på disse aktiviteter, viser det sig, at overvågningen ikke kun kan forstås negativt i termer af kontrol og disciplinering. Overvågning kan også have en tydelig omsorgsdimension - som f.eks. når velfærdsstaten udfører en tæt overvågning af sine borgere med henblik på at kunne tage sig af dem på bedst mulig måde (Lyon). Ligeledes er det blevet argumenteret, at overvågning kan være forførende (Bauman) eller have en underholdende funktion, sådan som man f.eks. ser det i nogle computerspil (Albrechtslund \& Dubbeld).

Denne opmærksomhed over for den pluralistiske, omnipræsente overvågning med varierende og nogle gange overraskende konsekvenser er endnu i sin vorden. Inden for overvågningsforskningen er der således stadig et stort behov for alternative, teoretiske ressourcer. Her kan kunsten spille en markant rolle, fordi der i denne sammenhæng netop findes eksperimenter og værker, som synliggør andre sider ved overvågningen end dem, forskningen - og den offentlige debat - normalt hæfter sig ved.

I det følgende præsenteres to sådanne eksempler på, hvordan en læsning af kunstneriske arbejder kan medvirke til at artikulere "nye", interessante aspekter ved overvågning.

\section{Når overvågningen bliver triviel - Hasan Elahi}

I 2003 begyndte Hasan Elahi en omfattende dokumentation af sit liv. Baggrunden var, at Elahi efter en flyrejse blev trukket til side af FBI-agenter, der tilsyneladende havde fået et tip om, at Elahi kunne være mulig terrorist. Elahi blev afhørt, og selvom han hurtigt blev sluppet fri, var han stadig under mistanke. Oplevelsen skræmte Elahi, som flyver verden rundt i forbindelse med sine kunstprojekter. Han kunne kun vente på, at han igen blev trukket til side. I denne situation fik han ideen til Tracking Transience: The Big Brother Project.

I kort form er det Elahis idé at offentliggøre så meget af sit liv som muligt. På den måde behøver FBI ikke at overvåge ham - han gør det selv, og informationerne stilles til rådighed på nettet (Elahi Tracking Transience). I dette arbejde indgår forskellige overvågningsteknologier. Med en GPS “tracker” Elahi sin aktuelle position, så man altid kan se, hvor han befinder sig. Med et kamera filmer han et væld af hændelser hver eneste dag. På hans hjemmeside kan man således se billeder af et utal af måltider og billeder af de toiletter, han har brugt. Samtidig har Elahi offentliggjort sine kreditkortkvitteringer, så man kan se, hvad han har købt.

Umiddelbart kunne man mene, at Elahi dermed opfører sig som fangen i det panoptiske fængsel. Angsten for overvågeren er så stor, at han retter ind og bliver sin egen overvåger. Han er nødt til at overvåge sig selv, ellers ender han i fangelejr: "Jeg er nødt til at sige dette: Denne opmærksomhed [som projektet giver] er det, som holder mig ude af Guantanamo for tiden. Så det er en ret god byttehandel" (Elahi npr). Denne reference til fængslet på Guantanamo og projektets undertitel, the "Big Brother Project", peger direkte på en tolkning, der ser værket som en ma- 
nifestation af en traditionel overvågningsforståelse. Men samtidig er det klart, at der er mere i Tracking Transience end denne enkle tolkning lader skinne igennem.

Elahis værk synes at stille spørgsmålet: Hvad nu, hvis der var en Big Brother? Hvad ville han se? Værket besvarer spørgsmålet med enorme mængder af triviel information. Billeder af bygninger, måltid efter måltid og toiletkumme efter toiletkumme. Vi får informationer om, hvor kunstneren er - nogle gange i en firkantet bygning i Californien, andre gange i New York. Man får med andre ord det klare indtryk, at Big Brother må kede sig ihjel.

Det skyldes, at overvågningens perspektiv aldrig får etableret sig i en relevant position (Gad \& Lauritsen). At overvågeren ser meget og kommer i besiddelse af mange informationer, betyder ikke, at overvågningen på nogen måde er afslørende. Informationerne er simpelthen ikke relevante. Elahi overvåger sit liv tæt, og vi kan kigge med. Betyder det så, at vi ved, hvem han er? Noget ved vi selvfølgelig - først og fremmest at han virker helt almindelig. Men vi får ikke noget interessant at vide. Vi kan ikke være sikre på, at han ikke er terrorist. Vi ved heller ikke, hvilket indtryk han gør på folk, og vi kender ikke hans intentioner og handlemåder. I et interview udtrykker Elahi denne pointe på følgende måde:

"Jeg må gøre det helt klart, at... når du ser værket online, så ser du ikke mit ansigt, du ser ikke mit navn, og du finder ikke noget, der identificerer mig. Du ser mine bankudskrifter. Du ser mine telefonopgørelser. Du ser mine toiletter. Men alligevel ... ved du absolut ingenting, fordi jeg kunne være hvem som helst.” (Ashraf)

Elahis værk har berettiget fået stor opmærksomhed, blandt andet fordi det så tydeligt tematiserer den overvågning, som borgere i USA - og andre steder - kan blive udsat for. I en dansk sammenhæng kan man f.eks. drage paralleller til den såkaldte logningsbekendtgørelse, som medfører, at informationer om alle danskeres telefonopkald, mailkorrespondance og internetbrug lagres og kan bruges af politiet i efterforskningsøjemed. Her er der ikke tale om endeløse rækker af toiletkummer og måltider, men der er stadig tale om en uhyre omfangsrig mængde af triviel information, hvoraf langt størstedelen må formodes at være lige så irrelevant som Elahis billeder.

En anden parallel kan trækkes til den "gør-det-selv-overvågning," som kan iagttages på medier som Facebook og Twitter. På disse tjenester offentliggør vi et hav af personlige informationer - hvad vi laver, hvordan vi har det, og hvad vi mener om dette og hint. Her er der også tale om en form for overvågning, der ikke kræver en overvåger - vi gør det selv. Men der er ikke tale om en panoptisk overvågning, hvor vi retter ind, fordi vi er nødt til at antage, at vi bliver overvåget. På Facebook er vi tilsyneladende mere eller mindre ligeglade med den mulige fangevogter; det er Elahi ikke - men han går jævnligt sine logfiler igennem og kan her se, hvem der overvåger ham. Det gør FBI og - en smule overraskende - Præsidentens kontor i Det Hvide Hus. Til forskel fra fangen i fængslet, kan Elahi se ind i tårnet.

Er Elahis værk så et argument for, at vi uden videre skal stille oplysninger til 
rådighed for staten? Ja, på en måde, men perspektivet er ikke en accept af statens overvågning. Der er således et tydeligt modstandsperspektiv i Tracking Transience. Elahis pointe er, at vi ikke kan beskytte vores privatliv ved at hegne det ind, men kun ved at opgive det (Elahi Colbert), og hvis tilstrækkelig mange mennesker gør det, bryder systemet sammen:

"Hvis 300 millioner mennesker begyndte at gøre dette, så skulle FBI potentielt også hyre 300 millioner mennesker for at holde trit med informationerne - måske flere - og sandsynligvis ville systemet kollapse. DDR prøvede dette for nogle få årtier siden; det viste sig ikke at være nogen god idé.” (Ashraf)

Vi kan med andre ord drukne Big Brother i mængder af information - og på den måde få lov til at være i fred.

Det interessante ved Elahis værk er, at det ikke forkaster Big Brother og panoptikon som relevante metaforer. Den kontrollerende og disciplinerende overvågning er en nærliggende mulighed. Men værket stiller samtidig spørgsmål til effektiviteten af denne overvågning. Med andre ord tydeliggør det grænserne for overvågningen det viser, hvordan man kan stække Big Brother og finde en vej ud af fængslet.

\section{Overvågning og krop - Stelarc}

Stelarc beskæftiger sig ikke på samme eksplicitte måde med overvågning som Elahi gør. Men Stelarcs værker tematiserer forhold, som har stor relevans for analyser af overvågning, især forholdet mellem krop og teknologi. Netop dette forhold er inden for overvågningsforskningen generelt blevet betragtet med bekymring. Det ses tydeligt i diskussioner af biometriske overvågningsteknologier, f.eks. dna, skanninger af iris og ansigtsgenkendelse, som er kendetegnet ved, at overvågningen retter sig direkte mod kendetegn ved subjektets krop. Af bl.a. brancheorganisationer fremhæves, at dette giver en stor grad af sikkerhed i identifikationen af den overvågede, men hos forskere har det også givet anledning til bekymring, at kroppen nu invaderes af overvågningsteknologi (van der Ploeg). Selvom Stelarcs værker ikke kan bruges til at fjerne denne bekymring, så viser de med al tydelighed, at bekymringen ikke kan rodfæstes i en generel teknologipessimisme, som ønsker at frigøre kroppen fra teknologi. Tværtimod ser Stelarcs budskab ud til at være, at et sådant frigørelsesprojekt hverken er ønskeligt eller muligt.

Stelarcs arbejde forbindes af mange med en række ophængninger ("suspension"), hvor Stelarc lod sig hænge op i kroge, som var gjort fast direkte i huden. Dermed fik kroppen en æstetisk, skulpturel værdi, men værkerne tematiserer også en afgivelse af kontrol - kroppen hænges op og føres rundt i rummet. Samtidig ser man en helt konkret kobling af krop og teknologi, hvor teknologien (krogene) ikke stopper ved kroppens grænse (huden), men trænger ind i den.

Disse forhold får en endnu mere fremtrædende placering i de af Stelarcs værker, som kredser om forskellige proteser og deres muligheder. Eksempelvis har Stelarc 
udviklet "en tredje arm", ligesom han har konstrueret et apparatur, som kunstneren bærer på ryggen, og som overtager styringen af hans overkrop. Fælles for flere af Stelarcs proteser er således, at de kan styres af andet (f.eks. input fra rummet) eller af andre (f.eks. andre personer, som giver input til protesen over nettet) end af kunstneren selv. Et centralt tema er således det kontroltab, som fjernstyringen af kunstnerens krop giver anledning til. Dette ses også, dog på en lidt anden måde, i Stelarcs idé om et ekstra øre, som påsættes kunstnerens underarm. Det er bl.a. meningen, at øret skal tilsluttes Internettet, således at personer på lang afstand kan høre det samme, som Stelarc hører med sine 'oprindelige' ører.

Som ovenstående eksempler viser, har Stelarc et profant forhold til kroppen. Et af hans slogans er, at kroppen er "utidssvarende" ("obsolete"). Problemet er, at vi helliggør kroppen og holder fast i dens oprindelige udformning samtidig med, at vi med store hast forandrer det miljø, som kroppen færdes i. I stedet må vi, ifølge Stelarc, affortrylle kroppen og betragte den som et objekt, som kan re-designes og dermed optimeres. Udgangspunktet for dette synspunkt er, at teknologi ikke er eller bør være - fremmed for kroppen. For Stelarc er teknologi således definerende for det at være menneske:

"Teknologi har altid været koblet til den evolutionære udvikling af kroppen. Teknologi er definerende for det at være menneske. Den er ikke et fjendtligt, fremmed objekt - den er en del af vores menneskelige natur. Den konstruerer den menneskelige natur" (Atzori \&Woolford).

Det er dette perspektiv, der gør, at Stelarcs arbejde indimellem bliver beskrevet med begreber som "cyborg" og "post-humanisme" (Farnell). Trods forskelle markerer begge begreber et opgør med den humanistiske forståelse af et selvberoende individ, der i visse situationer bruger teknologi (som værktøj). Teknologien er langt mere indgribende og kan ikke indfanges som blot et redskab. Teknologien er med til at gøre os til mennesker.

Stelarcs eksperimenter med sammenfiltringer af menneske og teknologi og med det kropslige kontroltab indeholder en tydelig overvågningsdimension, som får det til at løbe koldt ned ad ryggen på nogle. Mann og kollegaer siger:

"Vi har udvidet vores bevidsthed og kroppe gennem brugen af og tilpasning til vores teknologiske proteser. Dermed har vi skabt bagdøre, som det moderne panoptikon kan komme igennem” (Mann et al. 397).

Dermed opstår en interessant ambivalens i forholdet mellem krop og teknologi. Vi omgiver os med stadig mere avanceret teknologi, der kan indsamle og formidle et væld af informationer om os. Dette kan være til glæde og gavn, men samtidig er der, som Mann og kollegaer påpeger, tale om overvågningsteknologier. De teknologiske fremskridt sniger panoptikon ind ad bagdøren. Dette får Mann og kollegaer til at indtage en kritisk og reserveret attitude til Stelarcs arbejde: 
"Det moderne panoptikon er godt tjent med Stelarcs vision. Med vores udvidede kroppe, der er koblet til et allestedsnærværende netværk, og som kan blive invaderet og tilgået på afstand, vil overvågningskameraer, som nu gennemtrænger det offentlige rum, være et besværligt og overflødigt artefakt. I stedet kan man nemt forestille sig et samfund, hvor vi alle er adresserbare og lokaliserbare ved hjælp af eksisterende teknologier. Med det nuværende psyko-teknologiske klima i USA, for eksempel, er det totale overvågningsscenarie ikke langt ude.” (Mann et al. 2003: 393)

Det er ikke en overfortolkning at påpege, at Big Brother spøger i disse formuleringer. Pointen hos Mann og kollegaer ser således ud til at være, at teknologiseringen af kroppen og dens stadig stigende indspundethed i teknologiske netværk muliggør en realisering af det benthamske panoptikon.

Bekymringen kan være reel. Med teknologi følger øgede overvågningsmuligheder. Men problemet er, at løsningen ikke er en beskyttelse af den selvberoende og autonome krop mod at blive spundet ind i teknologi. For følger man Stelarc, findes denne krop ikke - og har aldrig gjort det:

"Det er ikke et spørgsmål om at tænke kroppen som en normal krop i dens biologiske fremtræden... i modsætning til de teknologiske systemer, som vi optræder med - for vi bruger alle sådanne teknologiske systemer. Når vi optræder på scenen, forstørrer og udvider vi måske disse interaktive systemer, men vi har alle computere og mobiltelefoner - vi fungerer alle i et teknologisk varmt og rigt miljø. Jeg tror ikke, at teknologi er noget fremmed, men det der konstruerer menneskelig civilisation.” (Cangiano)

Ud fra dette perspektiv kan det ikke nytte at se teknologi som sådan som en trussel mod det at være menneske. Man kan ikke fjerne teknologien og så samtidig være menneske. For Stelarc skal kroppen derfor ikke vikles ud af relationerne til teknologi, men nærmere vikles mest muligt ind i dem. Det betyder ikke, at teknologi altid er af det gode. Men Stelarcs arbejde viser, at teknologien giver os muligheder og nye erkendelser, men at udnytte dem kræver en villighed til at eksperimentere med teknologien og samtidig undlade at helliggøre kroppen.

For overvågningsforskningen er Stelarcs arbejde interessant, fordi det stiller etablerede dogmer på hovedet. Det kontroltab, som Stelarc eksperimenterer med og leder efter berigende elementer i, er det samme kontroltab, som mange overvågningsforskere frygter og advarer imod. At andre får kontrol over ens krop, er det ultimative tab af privacy, altså "retten til at være i fred.” Men ifølge Stelarc behøver det ikke at være udelukkende negativt. At vi kan dele krop og samarbejde over afstand, er også et løfterigt perspektiv. Teknologien giver mulighed for at forstærke mennesket og tune det til bedre at kunne håndtere de omgivelser, som mennesket selv har været med til at skabe. Mennesket, subjektet, kroppen er ikke et helligt sted, der trues af en invaderende teknologi. Tværtimod er det netop denne forestilling, vi må opgive for at kunne foranstalte interessante eksperimenter med teknologi. 
Det er netop her, mange overvågningsforskere har noget at lære af Stelarc. Det indebærer ikke et knæfald for ubegrundet teknologioptimisme, men blot en mere åben attitude, som inkluderer de muligheder, som teknologien byder for en ny kropslighed.

\section{Konklusion: Kunst som overvågningsteori}

De ovenstående eksempler har vist, hvordan kunsten kan være med til at åbne for forståelsen af overvågning som et komplekst og mangefacetteret fænomen. Dette bliver især tydeligt, når man har 1984/panoptikon-forståelsens dominans in mente. For Elahi gælder således, at han ikke afviser denne forståelse, men tydeligt viser dens begrænsninger. Big Brother kender ham ikke, og overvågeren bliver blændet af de mange informationer. I modsætning hertil er Stelarc ikke direkte engageret i en overvågningsdiskussion, men han tematiserer en positiv relation mellem krop og teknologi, som potentielt kan forandre overvågningsforskningens automatreaktion i forhold til tab af kontrol og privacy.

Meningen med disse eksempler har ikke været at bidrage til en generel overvågningsteori. Hvad overvågningsforskningen har brug for, er ikke generelle modeller. Der er således, med Haggertys ord, grund til at være "på vagt over for udsigten til at udvikle en overvågningsmodel, der meningsfuldt kan generaliseres til alle eller bare et betragteligt antal overvågningskontekster” (Haggerty 2006: 39). Men det er netop dette, der i vid udstrækning er sket med Orwells 1984, der ikke blot er blevet læst som en generel fortælling om, hvad overvågning er, men også foreskriver en bestemt normativ stillingtagen. At gentage denne fejltagelse ville være at misbruge kunsten. En af overvågningsforskningens udfordringer er således at åbne op for, at overvågning er et mangefacetteret fænomen, som ikke indfanges i modeller og simple læsninger. I dette arbejde kan kunsten nuancere og berige vores forståelse af overvågningens mange former.

\section{LITTERATURLISTE}

Aas, Katja Franko, Helene Oppen Gundhus \& Heidi Mork Lomell. "Introduction. Technologies of (in) Security.” Technologies of Insecurity. The Surveillance of Everyday Life. Red. Katja Franko Aas, Helene Oppen Gundhus \& Heidi Mork Lomell. Oxon: Routledge-Cavendish, 2009.

Albrechtslund, Anders. \& Lynsey Dubbeld. "The Plays and Arts of Surveillance: Studying Surveillance as Entertainment” Surveillance \& Society 3 (2005): 216-21.

Ashraf, Hena. "I can watch myself a lot better than they ever could" Muslim.Net 17. maj $2010<\underline{\text { http:// }}$ www.altmuslim.com/a/a/a/i_can_watch_myself_a_lot_better_than_they_ever_could/>

Atzori, Paolo \& Kirk Woolford. "Extended-Body: Interview with Stelarc". CTheory (1995) <http:// www.stanford.edu/dept/HPS/stelarc/a29-extended_body.html>

Bauman, Zygmunt. Flydende Modernitet. København: Hans Reitzel, 2006. 
Boyne, Roy. "Post-Panopticism.” Economy and Society 29 (2000): 285-307.

Cangiano, Serena. “STELARC’S EXTRABODY: THE TECHNOLOGIC CHIMERA.” Digimag49 (2009)

<http://www.digicult.it/digimag/article.asp?id=1641>

Elahi, Hasan. “Artist takes FBI surveillance a step further”. Interview. npr. 30. maj 2007.

Elahi, Hasan. "Tracking Transience: The Big Brother Project” <http://trackingtransience.net>

Foucault, Michel. Discipline and Punish: Birth of the Prison. London: Penguin Books, 1991.

Gad, Christopher \& Peter Lauritsen. "Situated Surveillance. An ethnographic study of fisheries inspection in Denmark." Surveillance and Society 7(2009): 49-57.

Koskela, Hille. "Hijacking Surveillance? The New Moral Landscape of Amateur Photographing." Technologies of Insecurity. The Surveillance of Everyday Life. Red. Katja Franko Aas, Helene Oppen Gundhus \& Heidi Mork Lomell. Oxon: Routledge-Cavendish, 2009.

Lyon, David. Surveillance Studies. An Overview. Cambridge: Polity Press, 2007.

Orwell, George. Nineteen Eighty-Four. Middlesex: Penguin Books, 1959.

Poster, Mark. The Mode of Information. Chicago: Chicago University Press, 1990.

Simon, Bart. "The Return of Panopticism: Supervision, Subjection and the New Surveillance." Surveillance \& Society 3 (2005): 1-20.

Stelarc - hjemmeside <http://www.stelarc.va.com.au

Van der Ploeg. "The illegal body: 'Eurodac' and the politics of biometric identification.” Ethics and Information Technology 1(1999): 295-302. 